\title{
CONVERSION OF ONLINE PURCHASE INTENTION INTO ACTUAL PURCHASE: THE MODERATING ROLE OF TRANSACTION SECURITY AND CONVENIENCE
}

\author{
Ni Luh Putu INDIANI ${ }^{1 *}$, Gabriel Aprinau FAHIK ${ }^{2}$ \\ 1, 2Warmadewa University, Bali, Indonesia
}

Received 14 October 2019; accepted 5 January 2020

\begin{abstract}
Online retail trade in Indonesia has grown dramatically in recent years. However, it is not being followed by an increase in the transaction completion ratio, with a cart abandonment rate of up to 70 percent. This indicates that the transition from online purchase intention to actual purchase is not as simple as postulated in the theory of planned behaviour (TPB); yet, there are other factors moderating the conversion. Therefore, this study aims to develop a model analysing the moderating role of perceived transaction security and convenience in the relationship between online purchase intention and actual purchase. Model development was also motivated by critics regarding TPB's robustness in explaining consumer purchase behaviour; therefore, this model is expected to enrich TPB by providing a more comprehensive picture in online purchase behaviour. The sample consisted of consumers who had shopped for retail products online. The proposed relationship was tested with partial least square method. Results showed that perceived transaction convenience has a positive and significant moderating effect, whereas perceived transaction security showed an insignificant moderating impact. This finding is noteworthy amid risky online purchase environment. Respondents' characteristics and alternative payment methods might explain the insignificant moderation. As a practical implication, it is recommended that online retailers improve online transaction convenience to increase the conversion rate.
\end{abstract}

Keywords: transaction security, transaction convenience, online purchase intention, actual purchase, online retail industry, online purchase behaviour.

JEL Classification: M31, M30, M21, M15.

\section{Introduction}

Indonesia's retail ecommerce market is undergoing a development phase, which is reflected in a significant increase in Indonesia's ecommerce transactions annually. Using the data reported by Bank of Indonesia, the value of Indonesia's ecommerce transactions in 2017 reached IDR 30,94 trillion or USD 2,18 million, rapidly increasing to IDR 77,76 trillion or USD 5,48 million in 2018 (CNBC, 2019). Over the past four years, ecommerce transactions in Indonesia have increased by 500 percent (Wartaekonomi, 2019). Rapid adoption of the internet in commerce activities is motivated by its advantages for both suppliers and consumers. Despite the rapid growth, there is a contradictory phenomenon in consumers' online purchase behaviour. When online shopping is increasingly popular, a large number of prospective consumers actually decide to cancel their purchase at the online payment stage. The increase in ecommerce transaction value is not followed by an increase in the ratio of online transaction completion. Baymard Institute (2019) released data on the transaction abandonment ratio, which is 70 percent over the past four years, on average, meaning that seven out of 10 consumers who were in the payment stage did not eventually complete the transaction. The time frame when the transaction was abandoned is after consumers decided to buy the product on the vendor's website, enter the payment stage, complete each required step, but leave the payment stage incomplete; in short, the transaction is not completed (Rajamma, Paswan, \& Hossain, 2009). This shows that even when the consumer has an intention to purchase online, it is not necessarily converted into an actual purchase.

A number of previous studies pointed to a similar conclusion. Thongpapanl and Ashraf (2011) found that online purchase intention does not necessarily encourage an actual purchase. It was also stated that online purchase intention can still be a predictor of an actual purchase,

*Corresponding author. E-mail: indi_arca@yahoo.com 
but intention alone is not sufficient to predict purchases. Wilson (2010) found that online purchase intention is not converted into an actual purchase; thus, of all online consumers who have entered the payment stage, only 50 percent eventually completed the online transaction. Even though online consumers have a high purchase intention, they leave in the middle of the transaction process (Negra \& Mzoughi, 2012).

The phenomenon above and empirical studies seem to contradict the theory of planned behaviour (TPB) and similar studies' findings. TPB postulates that intention is a strong predictor of behaviour. A study by Fogel and Schneider (2010), Guo and Barnes (2011), Hsieh and Liao (2011), Lim (2013), and Lin (2008) found that online purchase intention has a positive and significant impact on the actual purchase. This contradiction became the gap this study aimed to fill. From the phenomenon, it was suspected in this study that TPB has not been able to comprehensively explain consumer purchase behaviour in an online environment. While a transition from online purchase intention to actual purchase is not as simple, there are other factors influencing conversion.

Based on this assumption, field and empirical studies were conducted to identify factors that prevent consumers from making an online purchase. A survey sent to 2,732 respondents showed that almost 60 percent of respondents perceived a high risk of fraud in online transactions (Putri, 2016). Difficult and complex transactions were also mentioned as main obstacles in completing online transactions. In conducting online purchases, respondents expected guaranteed transaction security and convenience in completing transactions. From the survey results, we concluded that perceived transaction security and convenience are factors that inhibit online purchases.

Investigating empirical studies, perceived transaction security and convenience were mentioned as factors that influence actual purchase. Cunningham et al. (2005) found that perceived risk occurs at each stage of the purchase decision, and is at its peak at the transition stage from purchase intention to actual purchase. Chang, Fang, and Tseng (2012) and Sahney, Ghosh, and Shrivastava (2013) found that perceived risk due to unsecure online transaction and misuse of personal data prevented consumers from making online purchases. Online purchase is hindered by consumer perceptions that providing credit card data is unsafe and the data can be misused (Akturan \& Tezcan, 2012; Kim \& Lennon, 2010; Ling et al., 2011; Celik, 2011); also, the online payment system is unsecure (Akturan \& Tezcan, 2012; Zhao et al., 2010). Ozkan, Bindusara, and Hackney (2010) stated that transaction security drives the adoption of online transaction by consumers. In addition to security, transaction convenience is also found to be a significant factor that prevents consumers from conducting an online purchase. Rajamma et al. (2009) found that an inconvenient transaction is the cause of consumers not completing online transactions. A complex transaction is an inhibiting factor for online transaction adoption (Ozkan et al., 2010). Kim, Chung, and Lee (2011) and Chen, Hsu, and Lin (2010) found that a convenient transaction encourages consumers to complete an online transaction.

Thus, filling the research gap that the transition from online purchase intention to actual purchase is not that simple, and there must be other factors influencing conversion, we suspect that perceived transaction security and convenience moderate the conversion. Relevant studies analysing this moderating effect are still rare. Previous studies only focus on how these two factors directly influence online purchase intention and actual purchase. There is no study that has been found which analyses the moderating effect of these two factors or other external factors on the conversion of online purchase intention to actual purchase. This model development is expected to enrich TPB in explaining consumer purchase behaviour in an online environment to provide a more comprehensive picture. This model development was also motivated by a number of critics of TPB's robustness in explaining consumer purchase behaviour. Sheppard (1988) argued that the influence of intention on behaviour seems to oversimplify the decision-making process, and it would only prove significant in a situation with a number of restrictions. Bray (2008) added that TPB does not give space or include factors that hinder behaviour, in addition to factors that encourage behaviour. Understanding the behaviour of a buyer's decision is one of the basic prerequisites of creating a successful marketing strategy (Lendel \& Varmus, 2015). Based on the research background, the main purposes of this research are first, to examine the influence of online purchase intention on actual purchase, and second, to examine the moderation effect of perceived transaction security and convenience on the relationship between online purchase intention and actual purchase.

\section{Literature review}

\subsection{Theory of Planned Behaviour (TPB)}

According to this theory, consumer behaviour is shaped by attitude, subjective norm, and perceived behavioural control (PBC), which later forms intention, and intention then drives how one behaves. This theory is the foundation of this study, which analyses the effect of intention on actual purchase. The three intention-forming variables in TPB are explained as follows:

- Attitude: the concept is the degree to which behaviour is perceived as positive or negative.

- Subjective norms: a person's perception of certain behaviour, where it is influenced by the judgment of those around them who are considered influential, such as parents, partners, and friends.

- Perceived behavioural control (PBC): perception of the ease or difficulty of carrying out certain behaviour. $\mathrm{PBC}$ is determined by the presence of factors that can facilitate or hinder a person's ability to perform the behaviour. 
TPB is one theory of behaviour with a high predictive power and is used to predict human behaviour in many fields. Studies that often refer to this theory are in marketing (buying behaviour, advertising, public relations), behaviour in new environments such as online, and in new issues such as eco-friendly behaviour, sustainability issues, and entrepreneurial behaviour. This study analyses the impact of online purchase intention on online purchase behaviour; therefore, TPB is a very important theory as the foundation of this research.

\subsection{Perceived risk theory}

Risk is formed by two dimensions: uncertainty and consequences (Cunningham, 1967). Uncertainty is a function of an unknown future which cannot be controlled and predicted. Consequences are limited to negative consequences, and in this research, negative consequences are those that may arise as a result of an online purchase. Online perceived risk is the consumer belief of potential negative consequences due to an online transaction, and related risks consist of financial, performance, social, psychological, physical, and time risk (Nepomuceno et al., 2012, Zhao et al., 2008). Online transaction is vulnerable to fraud, which potentially inflicts financial loss to online consumers. Financial risk predominantly inhibits consumers making an online purchase (D'Alessandro, Girardi, \& Tiangsoongnern, 2012; Liu \& Forsythe, 2010; Xu, Lin, \& Shao, 2010); therefore, perceived risk theory is important in explaining online purchase behaviour.

A survey of Indonesian consumers showed that almost 60 percent of respondents perceived a high risk of fraud in online transactions, which could result in financial loss. Consumers search for information as a strategy to lower risk to a manageable level (Bettman, 1973). Online consumers search and rely on much more information than offline consumers before making a purchase (Thongpapanl \& Ashraf, 2011). Consumers seek information on how secure the online transaction is with the online retailer to reduce perceived financial risk. Therefore, perceived financial risk is determined by the security level of the online transaction. If the online transaction is relatively safe, is equipped with a secure online payment mechanism, provides a favourable exchange and return policy, along with a money-back guarantee, the perceived financial risk can be reduced. This assumption becomes the foundation for this study to analyse the moderating role of perceived transaction security in the conversion of online purchase intention to actual purchase.

\subsection{Perceived transaction security}

In an online environment, security is defined as the ability of the online retailer to protect consumer personal information and their financial data from being stolen. Therefore, perceived security is the consumer assessment that an online retailer can process online transactions without mistakes and all personal information is kept confidential to avoid negative consequence. Online transaction security continues to dominate discussions about ecommerce. Park and Kim (2006) argued that security assurance plays an important role in creating trust by reducing consumer anxiety regarding the misuse of personal data and unsecure transactions. When the level of security assurance is acceptable and meets consumers' expectations, they may be willing to disclose their personal information and conduct their purchases with a sense of security.

As a new transaction channel, online shopping involves more uncertainty and risk than offline shopping. The absence of face-to-face interaction makes online transactions prone to fraud. In addition, with its online nature, customers are unable to physically inspect a product, thus, raising uncertainty and risk. Some important reasons why customers do not buy products or services on the internet are the safety of online shopping and the privacy of personal information. Research findings, in general, have shown that consumer intention to shop online is strongly influenced by their perception of the transaction security level possessed by an online retailer. Transaction security and privacy become important issues in online shopping because almost every website asks for personal identity such as customer's name, e-mail address, telephone number, mailing address, and credit card details. Thus, it can be concluded that perceived transaction security is an important factor influencing an actual purchase in an online environment.

Perceived transaction security is measured by several indicators, including: transaction security assurance; information confidentiality and personal data not being misused (Raman \& Annamalai, 2011); online retailer possessing secure payment mechanisms (Kim \& Lennon, 2013); ensuring the security of credit card and personal information provided by consumers (Lee, Au, \& Law, 2013; Lowry et al., 2012); online retailer will not commit fraud (Liu et al., 2013); online retailer offers exchange and return policy and also a refund guarantee if products are not delivered or do not match the description (Chen et al., 2010); and online retailer provides privacy policy to assure that it will not use the consumers' personal data without permission (Lee et al., 2013).

\subsection{Perceived transaction convenience}

Internet has made shopping easier where consumers do not need to deal with traffic, parking, and commuting from one store to another. Consumers need only use their computers and connect to the internet. In the ecommerce environment, convenience is defined as pleasure and happiness when conducting online shopping, not when the shopping process is completed (Monsuwe, Dellaert, \& de Ruyter, 2004). If consumers feel happy and stimulated during their shopping experience, they are very likely to engage in subsequent shopping behaviour, explore further, engage in unplanned purchases, and look for more products and categories (Childers et al., 2001). Perceived transaction convenience is the consumer's evaluation that 
online transaction is a simple and fun process so that there is no psychological burden when undergoing the process. Inconvenience transaction is the cause of consumers not completing an online transaction (Rajamma et al., 2009). Kim et al. (2011) and Chen et al. (2010) found that a convenient transaction encourages consumers to make an online transaction.

Shen, Li, and DeMoss (2012) measured perceived transaction convenience with several indicators including: ease of ordering procedure, ease of product search, and ease of payment. In addition, perceived transaction convenience is also reflected in a quick transaction process (Rajamma et al., 2009); no significant additional costs during payment process (Indiani et al., 2015); uncomplicated transaction mechanisms (Kim et al., 2011); availability of various payment methods and online retailer displays detailing ordering information before proceeding to the payment stage (Chen et al., 2010).

\section{Hypotheses development}

\subsection{Online purchase intention and actual purchase}

TPB postulates that attitudes, subjective norms, and $\mathrm{PBC}$ form intentions. Intention then affects how someone behaves. This theory is the foundation of the current study, which analyses the influence of intention on online purchase behaviour. TPB states that intention is a strong predictor of behaviour. Mei, Nan, and Ping (2011) found online purchase intention formed by eWOM positively and significantly affects actual purchase. Using the technology acceptance model, Lim (2013) found a positive and significant impact of online purchase intention on actual purchase. Guo and Barnes (2011) explored online purchase intention formed by intrinsic, extrinsic, and social influences, and found that online purchase intention is a significant predictor of actual purchase. Actual purchase is influenced positively and significantly by online purchase intention formed by attitudes and beliefs (Hsieh \& Liao, 2011; Lin, 2008). These empirical findings underlie the following hypothesis:

H1: Online purchase intention has a positive and significant influence on actual purchase.

\subsection{Perceived transaction security}

Online transaction bears high risk due to a high level of uncertainty and its uncontrollable nature. Financial risk was most often cited as the dominant type of risk hindering online purchase; it is the risk of losing money due to an online transaction. Financial risk is related to the security level of the transaction. Perceived transaction security is the consumer's judgment that online transaction is errorfree and guarantees the confidentiality of personal data; therefore, negative consequences could be minimised. A number of studies found that perceived transaction security is a significant factor that prevents consumers from making an online purchase. D'Alessandro et al. (2012) and $\mathrm{Xu}$ et al. (2010) found that an online purchase decision is influenced by perceived transaction security. Park and Jun (2003) found that perceived transaction security precludes an online purchase. Chang et al. (2012) and Sahney et al. (2013) found that unsecure online transaction and misuse of personal data prevent consumers from making an online purchase. Roy, Raju, and Mandal (2017) argued that transaction details are crucial factors in the consumer decision-making, in alignment with Ozkan et al. (2010) finding that security and convenience are the determining factors in consumer adoption of online transaction. Based on these findings, perceived transaction security is an important factor that influences buying behaviour in an online environment. Cunningham et al. (2005) found that perceived risk, especially financial risk, is at the highest level at the transition stage from intention to actual purchase. Thus, perceived transaction security is thought to be a factor that significantly influences the conversion of online purchase intention into an actual purchase. Based on this empirical study, the research hypothesis can be formulated:

$\mathrm{H} 2$ : Perceived transaction security moderates the influence of online purchase intention on actual purchase.

\subsection{Perceived transaction convenience}

Perceived transaction convenience is the consumer's judgment that an online transaction is a simple and pleasant process, therefore giving no psychological burden when undergoing the process. An uncomfortable transaction is the reason why consumers do not complete an online transaction (Rajamma et al., 2009). Furthermore, it was stated that the online transaction becomes less convenient due to technical errors during the process, a slow process in uploading data, a lengthy order form, and a complex registration process. Ozkan et al. (2010) found that a complicated transaction is the inhibiting factor for the adoption of online transactions by consumers. A transaction is considered complicated when the online payment system is difficult to understand and navigate. Kim et al. (2011) and Chen et al. (2010) found that a convenient transaction encourages consumers to conduct online transactions. Furthermore, Chen et al. (2010) stated that a convenient online transaction must have online support facilities, detailed transaction information, varied payment methods,

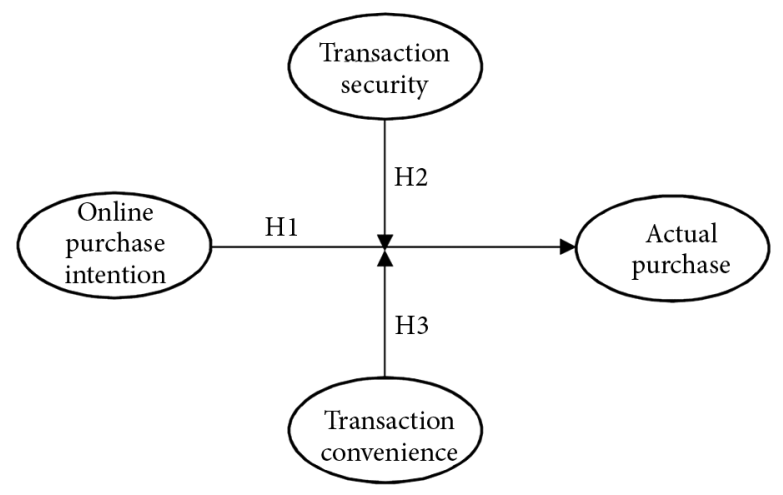

Figure 1. Conceptual framework 
and order confirmation. Based on these empirical studies, this study argued that perceived transaction convenience significantly influences the conversion of online purchase intention into actual purchase. The research hypothesis can be formulated:

H3: Perceived transaction convenience moderates the influence of online purchase intention on actual purchase.

The conceptual framework is illustrated in Figure 1.

\section{Research method}

\subsection{Sample and data collection}

Data collection was conducted through a survey using a questionnaire as the instrument. A preliminary survey was conducted on 30 respondents to assess construct measurement instruments. The results showed that research constructs were one-dimensional and reliable with alpha levels above 0.6 . The survey was then conducted on 105 consumers who had shopped for retail products online. The number of samples was determined using Slovin's formula. Slovin's formula allows a researcher to sample the population with a desired degree of accuracy, determining the sample size needed to ensure a reasonable accuracy of the results (Ellen, 2018). Slovin's formula is written as:

$$
\begin{aligned}
& n=N \div(1+\mathrm{Ne} 2) ; \\
& n=31535000 \div(1+(31535000 \times 0.12) ; \\
& n=31535000 \div(1+315350) ; \\
& n=99,99,
\end{aligned}
$$

where $n=$ number of samples; $N=$ total population; $e=$ error tolerance.

The population in this study is online consumers in Indonesia, constituting 11.9 percent of Indonesia's total population (Kompas, 2018), which is 265 million people; therefore, 11.9 percent of the total population is 31.535.000 people. The error tolerance used in this study is 0.1 , as mentioned by Sarwono (2013) and Cramer and Howitt (2004) that the threshold applied in social science research commonly ranges from $<0.01$ to 0.1 . From the calculation using Slovin's formula, the size of the sample recommended for this study is 99.99 or 100 . In determining sample size, Hair et al. (2010) also stated that the minimum ratio of observations to measured variables is 5:1. This study uses 16 measured variables; therefore, five times the number of measured variables are 80 observations or samples. This study received 105 samples which have met the minimum criteria required in Slovin's formula and Hair et al. (2010).

To ensure sample representativeness, the sample is proportionately stratified to the population profile. Hijrah (2017) mapped the profile of Indonesia's online consumers, as follows: online consumers consisted of 53 percent women and 47 percent men; consumers who were familiar and very familiar with online shopping activities were 90 percent and the remaining 10 percent were novice or less familiar; consumers with an academy or university degree were over 80 percent; and in terms of age, Kompas (2018) stated that the majority of Indonesia's online consumers were aged 15-34 years, which is equal to 80 percent. This online consumer profile became the basis for taking a sample or respondents; therefore, respondents' profile in this study is similar to Indonesia's online consumers profile in terms of gender, age, education level, and familiarity in online shopping, as shown in Table 1. To further enhance sample representativeness, respondents were taken from five cities in Indonesia: Jakarta, Surabaya, Medan, Bandung, and Makassar, under consideration that those cities have the highest online shopping penetration in Indonesia, with a penetration rate above 57 percent (Marketeer, 2018). Thus, these cities are the proper area to observe online purchase behaviour to obtain an accurate and comprehensive picture of consumer purchase behaviour in emerging online retail market.

Aside from a stratified technique, non-probability purposive judgment sampling technique was also used to select the sample. This study set the sample criteria, who were consumers who shopped online in the most recent month. These time criteria were intentional so that respondents could provide accurate responses to the research questionnaire, and a span of one month's time allowed respondents to still clearly recall their experience in performing online purchases. This aimed to anticipate bias that could potentially arise if there were no set time criteria; where the response could be less accurate because respondents' experience was too long in the past, this could lead to sample became less representative of the population. Respondents filled out a questionnaire and gave perceptional assessments to a number of statements representing each research construct. Rating scale 1 (strongly disagree) to 5 (strongly agree) is used to rate respondents' response on the construct as suggested by Cooper and Schindler (2014).

\subsection{Construct measurement}

Construct measurements were adopted from relevant empirical studies to ensure the validity and reliability of measurements. The selection of measurements was based on the criteria of quantity, quality, and relevance. Perceived transaction security is measured by five indicators: (1) secure online payment mechanism, adapted from Kim and Lennon (2013); (2) online vendors will not commit fraud, adapted from Liu et al. (2013); (3) favourable exchange and return policy and (4) provide money-back guarantee, adapted from Chen et al. (2010); (5) favourable privacy policy, adapted from Lee et al. (2013). Perceived transaction convenience is measured by five indicators: (1) quick transaction process, adapted from Rajamma et al. (2009); (2) no extra fees during transaction, adapted from Indiani et al. (2015); (3) provide various payment methods and (4) displaying order detail information, adapted from Chen et al. (2010); (5) uncomplicated transaction mechanism, adapted from Kim et al. (2011). Online purchase intention is measured by three indicators: (1) intention to shop online, (2) willing to shop online in the near future, (3) 
willing to provide credit card information, adapted from Indiani et al. (2015). Actual purchase is measured by three indicators: (1) has been shopping online, (2) shop online frequently, (3) has bought many products online, adapted from Indiani et al. (2015).

\subsection{Data analysis}

The structural model was tested with partial least square (PLS) technique, which combines multiple regression and factor analysis to perform a simultaneous examination upon either the relationship between the measured variables and the latent constructs or the relationship between latent constructs. PLS was also used to test hypothesised moderation effects in this study.

\section{Result}

\subsection{Respondent characteristics}

Respondents were predominantly young consumers aged 20 to 30 , and 67 percent had a college degree, as shown in Table 1 . There was a rough parity between the number of male and female respondents. Large parts of respondents were familiar with online shopping activities, with 85 percent of respondents having a moderate to high level of familiarity.

Table 1. Respondent characteristics

\begin{tabular}{|l|c|}
\hline \multicolumn{1}{|c|}{ Characteristic } & $\%$ \\
\hline Gender & \\
Male & 42 \\
Female & 58 \\
\hline Age & \\
Below 20 & 9 \\
$20-30$ & 73 \\
$31-40$ & 9 \\
$41-50$ & 5 \\
Above 50 & 5 \\
\hline Education & 25 \\
High school & 9 \\
Diploma & 57 \\
Bachelor & 8 \\
Master & 2 \\
Doctor & \\
\hline Degree of familiarity with online shopping & 15 \\
Not familiar & 64 \\
Familiar & 21 \\
Very Familiar & \\
\hline
\end{tabular}

\subsection{Measurement model evaluation}

The results showed a $\rho$ value $<0.001$ for all indicators, as shown in Table 2, which implies that all indicators measure the construct significantly (Hair et al., 2010). The loading factor of each indicator is above 0.5 , indicating that all indicators measure the latent construct well (Hair et al., 2010). Average Variance Extracted (AVE) values of each construct are above 0.5 , meaning that all constructs have adequate convergence, and Construct Reliability (CR) values of each construct are above 0.8 , demonstrating that all indicators consistently reflect the same latent construct (Hair et al., 2010).

Table 2. Construct validity

\begin{tabular}{|c|c|c|c|c|c|}
\hline $\begin{array}{l}\text { Cons- } \\
\text { truct }\end{array}$ & $\begin{array}{l}\text { Measurement } \\
\text { Item }\end{array}$ & $\rho$ value & $\begin{array}{l}\text { Loading } \\
\text { Factor }\end{array}$ & AVE & $\mathrm{CR}$ \\
\hline \multirow{5}{*}{$\begin{array}{l}\text { Per- } \\
\text { ceived } \\
\text { Trans- } \\
\text { action } \\
\text { Secu- } \\
\text { rity } \\
\text { (X1) }\end{array}$} & $\begin{array}{l}\text { X1.1 Secure } \\
\text { online payment } \\
\text { mechanism }\end{array}$ & $<0.001$ & 0.56 & \multirow{5}{*}{0.50} & \multirow{5}{*}{0.81} \\
\hline & $\begin{array}{l}\text { X1.2 Online } \\
\text { vendors will not } \\
\text { commit fraud } \\
\end{array}$ & $<0.001$ & 0.62 & & \\
\hline & $\begin{array}{l}\text { X1.3 Favourable } \\
\text { exchange and } \\
\text { return policy }\end{array}$ & $<0.001$ & 0.81 & & \\
\hline & $\begin{array}{l}\text { X1.4 Provide } \\
\text { money-back } \\
\text { guarantee }\end{array}$ & $<0.001$ & 0.85 & & \\
\hline & $\begin{array}{l}\text { X1.5 Favourable } \\
\text { privacy policy }\end{array}$ & $<0.001$ & 0.49 & & \\
\hline \multirow{5}{*}{$\begin{array}{l}\text { Per- } \\
\text { ceived } \\
\text { Trans- } \\
\text { action } \\
\text { Conve- } \\
\text { nience } \\
\text { (X2) }\end{array}$} & $\begin{array}{l}\text { X2.1 Quick } \\
\text { transaction } \\
\text { process }\end{array}$ & $<0.001$ & 0.74 & \multirow{5}{*}{0.54} & \multirow{5}{*}{0.85} \\
\hline & $\begin{array}{l}\text { X2.2 No extra } \\
\text { fees during } \\
\text { transaction } \\
\end{array}$ & $<0.001$ & 0.73 & & \\
\hline & $\begin{array}{l}\text { X2.3 Provide } \\
\text { various payment } \\
\text { methods }\end{array}$ & $<0.001$ & 0.66 & & \\
\hline & \begin{tabular}{|l}
$\mathrm{X} 2.4$ \\
Uncomplicated \\
transaction \\
mechanism \\
\end{tabular} & $<0.001$ & 0.82 & & \\
\hline & $\begin{array}{l}\text { X2.5 Displaying } \\
\text { order detail } \\
\text { information }\end{array}$ & $<0.001$ & 0.73 & & \\
\hline \multirow{3}{*}{$\begin{array}{l}\text { Online } \\
\text { Pur- } \\
\text { chase } \\
\text { Inten- } \\
\text { tion } \\
\text { (X3) }\end{array}$} & $\begin{array}{l}\text { X3.1 Intend to } \\
\text { shop online }\end{array}$ & $<0.001$ & 0.77 & \multirow{3}{*}{0.62} & \multirow{3}{*}{0.83} \\
\hline & $\begin{array}{l}\text { X3.2 Will shop } \\
\text { online in the near } \\
\text { future }\end{array}$ & $<0.001$ & 0.87 & & \\
\hline & $\begin{array}{l}\text { X3.3 Willing to } \\
\text { provide credit } \\
\text { card information }\end{array}$ & $<0.001$ & 0.73 & & \\
\hline \multirow{3}{*}{$\begin{array}{l}\text { Actual } \\
\text { Pur- } \\
\text { chase } \\
\text { (Y1) }\end{array}$} & $\begin{array}{l}\text { Y1.1 Has been } \\
\text { shopping online }\end{array}$ & $<0.001$ & 0.70 & \multirow{3}{*}{0.71} & \multirow{3}{*}{0.88} \\
\hline & $\begin{array}{l}\text { Y1.2 Shop online } \\
\text { frequently }\end{array}$ & $<0.001$ & 0.91 & & \\
\hline & $\begin{array}{l}\text { Y1.3 Has bought } \\
\text { many products } \\
\text { online }\end{array}$ & $<0.001$ & 0.91 & & \\
\hline
\end{tabular}

Discriminant validity measures the extent to which a construct differs from other constructs, and where a construct is unique and explains phenomena that is not explainable by other constructs. The discriminant validity test is conducted by comparing the construct's AVE value with a square correlation between construct and the 
construct associated with it. If the AVE value is greater than the quadratic correlation between constructs, then discriminant validity has been fulfilled (Hair et al., 2010). The results showed that the AVE value of each construct is greater than the construct's square correlation with other constructs, as shown in Table 3, which indicates a good discriminant validity.

Table 3. Discriminant validity

\begin{tabular}{|c|c|c|c|c|}
\hline $\begin{array}{l}\text { Cons- } \\
\text { truct }\end{array}$ & $\begin{array}{c}\text { Transaction } \\
\text { Security }\end{array}$ & $\begin{array}{l}\text { Online } \\
\text { Purchase } \\
\text { Intention }\end{array}$ & $\begin{array}{c}\text { Actual } \\
\text { Purchase }\end{array}$ & $\begin{array}{c}\text { Transaction } \\
\text { Conve- } \\
\text { nience }\end{array}$ \\
\hline $\begin{array}{l}\text { Trans- } \\
\text { action } \\
\text { Security }\end{array}$ & 0.683 & & & \\
\hline $\begin{array}{l}\text { Online } \\
\text { Purchase } \\
\text { Inten- } \\
\text { tion }\end{array}$ & 0.389 & 0.790 & & \\
\hline $\begin{array}{l}\text { Actual } \\
\text { Purchase }\end{array}$ & 0.319 & 0.648 & 0.845 & \\
\hline $\begin{array}{l}\text { Trans- } \\
\text { action } \\
\text { Conve- } \\
\text { nience }\end{array}$ & 0.552 & 0.468 & 0.483 & 0.735 \\
\hline
\end{tabular}

Diagonal value: Sq. root of AVE; Non-diagonal value: interconstruct correlations

\subsection{Structural model evaluation}

$\mathrm{R}$-square value of actual purchase is 0.45 , indicating that perceived transaction security, convenience, and online purchase intention explain 45 percent variation in actual purchase, while the remaining 55 percent is explained by other constructs outside the model. The goodness-of-fit (GoF) value of the proposed model is 0.471 . GoF shows a good fit for the model, representing the similarity of the theory (estimated covariance matrix) to reality (the observed covariance matrix). Criterion for model strength based on GoF according to Ghozali and Latan (2012) are as follows: 0.36 (large), 0.25 (medium), and 0.10 (small). This means that with GoF value of 0.471 , the model is a good predictive model.

\subsection{Hypothesis testing}

In hypothesis testing, the hypothesis is accepted if the $\rho$ value is below 0.1 , the threshold applied in social science research, which commonly ranges from $<0.01$ to 0.1 (Sarwono, 2013; Cramer \& Howitt, 2004). As shown in Table 4, H1 is accepted where a positive and significant relationship is confirmed between online purchase intention and actual purchase. Hypothesis 2 is rejected, since it shows that perceived transaction security has an insignificant moderating influence on the relationship between online purchase intention and actual purchase. The 3D moderating graph in Figure 2 shows the moderation relationship. Hypothesis 2 states that transaction security strengthens the influence of online purchase intention on actual purchase. To depict the hypothesis, the graph should be smoothly sloped from left to right, which indicates that low transaction security weakens the impact of online purchase intention on actual purchase. However, the result shows that the graph is not sloping to the right, but has an irregular pattern instead. This denotes that when transaction security is low, the impact of online purchase intention on actual purchase is strong. Likewise, when transaction security is high, the impact of online purchase intention on actual purchase remains strong. This implies that an improvement in transaction security does not significantly strengthen the relationship between online purchase intention and actual purchase.

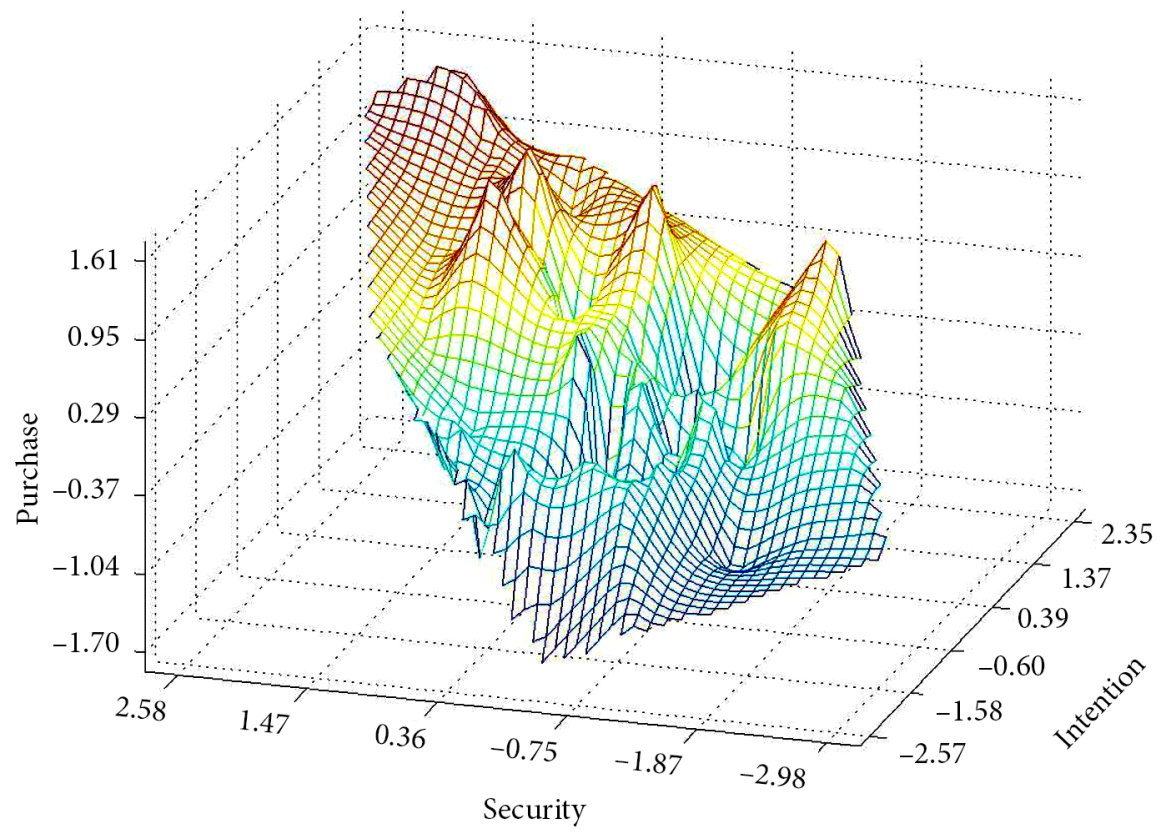

Figure 2. 3D Graph for the moderating effect of transaction security 
Table 4. Hypothesis testing

\begin{tabular}{|l|c|c|c|}
\hline \multicolumn{1}{|c|}{ Construct } & $\begin{array}{c}\text { Path } \\
\text { Coefficient }\end{array}$ & $\rho$ value & Result \\
\hline $\begin{array}{l}\text { (H1) Online Pur- } \\
\text { chase Intention -> } \\
\text { Actual Purchase }\end{array}$ & 0.660 & $<0.001$ & Accepted \\
\hline $\begin{array}{l}\text { (H2) Perceived } \\
\text { Transaction Security } \\
\times \text { Online Purchase } \\
\text { Intention -> Actual } \\
\text { Purchase }\end{array}$ & 0.02 & 0.44 & Rejected \\
\hline $\begin{array}{l}\text { (H3) Perceived } \\
\text { Transaction Con- } \\
\text { venience } \times \text { Online } \\
\text { Purchase Intention } \\
->\text { Actual Purchase }\end{array}$ & 0.14 & $<0.1$ & Accepted \\
\hline
\end{tabular}

Hypothesis 3 is accepted where perceived transaction convenience has a statistically significant moderating influence on the relationship between online purchase intention and actual purchase. The moderation effect is depicted in Figure 3. The graph shows a sloping pattern from left to right. The influence of online purchase intention on actual purchase significantly strengthens when transaction convenience improved from negative to positive. When transaction convenience is higher, the influence of online purchase intention on actual purchases becomes stronger. Thus, transaction convenience positively and significantly moderates the influence of online purchase intention on actual purchase.

\section{Discussion}

\subsection{Theoretical contribution}

Influence of online purchase intention on actual purchases

Results showed that online purchase intention has a positive and significant impact on actual purchase. The higher the intention to shop online, the higher the actual purchase shown in frequent online purchases and more quantities. This finding aligns with TPB, which states that intention encourages behaviour. Previous empirical studies found similar results that online purchase intention has a positive and significant impact on actual purchase (Mei et al., 2011; Lim, 2013; Guo \& Barnes, 2011; Hsieh \& Liao, 2011; Lin, 2008).

Actual purchase is represented by the online purchase made, frequent purchases, and the quantity purchased. Online purchase intention is represented by a willingness to depend on online vendors regarding personal data security, the desire to shop online, and make online purchases in the future. Consumers will only perform online transactions if they have the desire to shop online, and most importantly, are willing to entrust their personal data security to an online vendor. This desire and willingness are a prerequisite for consumers to conduct an online purchase.

Moderating role of perceived transaction security on the influence of online purchase intention on actual purchase

Results indicated that perceived transaction security does not moderate the influence of online purchase intention on actual purchase. This indicates that a more secure online transaction does not significantly strengthen the influence of online purchase intention on actual purchase. Additionally, it does not support previous research findings which stated that perceived transaction security has a significant effect on actual purchase. This finding is noteworthy, considering that online shopping holds risks and is prone to fraud. This insignificant influence can be explained by the shift towards digitalisation. In the digital era, technology is massively integrated into everyday life and business (Kowalska, 2012). Consumers gain tremendous benefits from digitising shopping activities (Ganac, 2018). Therefore, they are weighing the benefits rather than the risks when shopping online. Although purchases made over the internet are often associated with higher

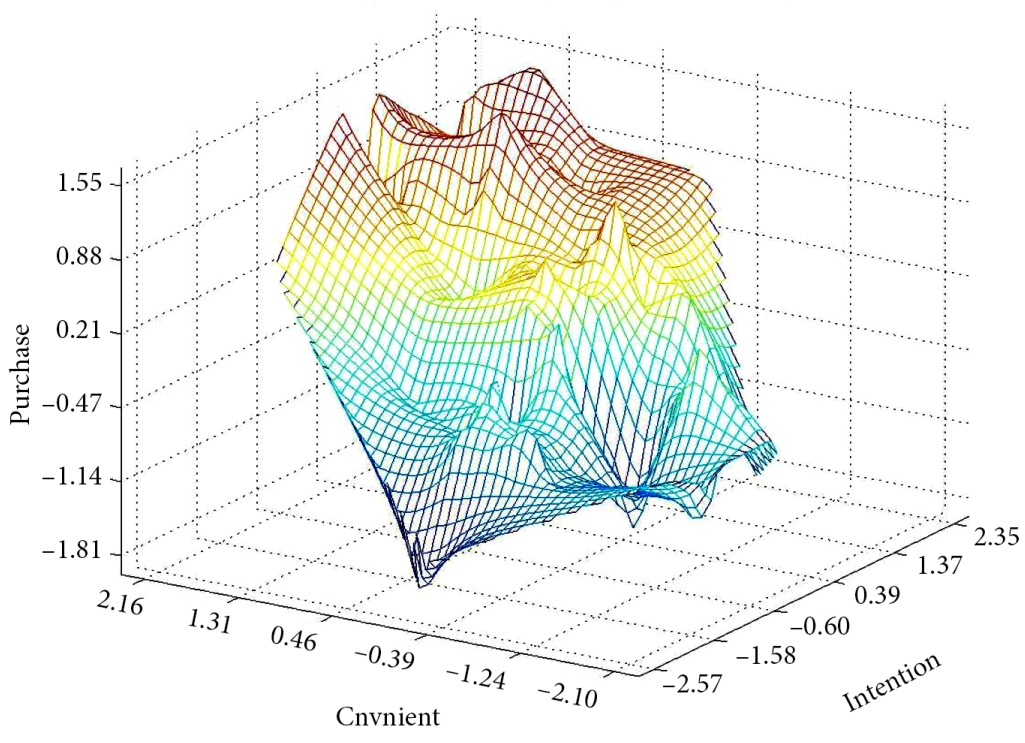

Figure 3. 3D Graph for the moderating effect of transaction convenience 
levels of risk than those done in traditional stores, this form of sale also provides many prospects and convenience, and they are continuously growing in popularity (Kowalska, 2012). It seems that benefits obtained from online shopping are perceived to be higher than the risk. This makes sense, since the respondents of this study are predominantly young consumers and familiar with online shopping activities. Young consumers possess a high level of knowledge of online shopping activities and can navigate the digital world to pursue various benefits (Kowalska, 2012). Therefore, with their intelligence, young consumers can recognise fraud indications, and are thus exposed to a low level of risk, as found by Sims and Xu (2012), where consumers who are familiar with online shopping and are more educated are exposed to a lower level of risk.

In addition, the cash on delivery (COD) payment method becomes the solution to the highly risky online transaction. This method has been widely implemented by online retailers in Indonesia. Although transaction security in the online platform is low, it does not affect actual purchase since consumers can take advantage of the COD method where consumers will only make a payment when their order is delivered with the right specification. Thus, lowering fraud risk which is highly associated with online purchases. This explains why perceived transaction security insignificantly moderates the influence of online purchase intention on actual purchase.

\section{Moderating role of perceived transaction convenience on the influence of online purchase intention on actual purchase}

Results indicated that perceived transaction convenience significantly moderates the influence of online purchase intention on actual purchase. This means that convenient online transaction strengthens the influence of online purchase intention on actual purchase. Convenient transaction is characterized by a quick and simple transaction process, providing a variety of payment methods, no significant extra price/cost in the middle of the transaction process, and online vendors displaying order detail information before proceeding to the payment stage. Those are able to smooth the transition of online purchase intention into an actual purchase. This makes sense because, in today's fast digital era, speed, transparency, and accuracy are important for consumers. In the current era of digitalisation, practicality and convenience are aspects that are increasingly sought by consumers when shopping (Gao \& Bai, 2014). Providing a variety of payment methods and a quick transaction process reflect practicality, whereas displaying order detail information before proceeding to the payment stage and an uncomplicated transaction mechanism mean convenience. These aspects fulfil consumers' expectations when conducting online transactions, therefore facilitating the conversion of online purchase intention into actual purchase.

In addition, having no significant extra price/cost in the middle of the transaction process is also important in ensuring a smooth transition from purchase intention into actual purchase. Cognitive dissonance theory states that an individual will experience stress when given information that is contrary to his attitude, intention, or value, and one step that might be taken is to change the attitude, intention, or value that has been adopted (Festinger, 1957). This condition occurs when the consumer is faced with unfavourable ordering conditions during an online transaction, in the form of additional costs not mentioned earlier. Additional costs are generally charged at the online payment stage, where vendors charge an additional fee, such as taxes, service fee, handling fee, etc. that were not initially communicated. Mullikin (2003) found that when the price is beyond consumer expectation, the consumer then cancels or postpones the purchase.

\subsection{Practical contribution}

Actual purchases are the objectives of retail industry. Results indicate that transaction convenience is an important factor that needs to be improved to facilitate the transition of online purchase intention into actual purchase. To improve transaction convenience, online vendors need to upgrade their performance on a number of indicators, which are: a quick and uncomplicated transaction process, providing a variety of payment methods, no significant extra price/cost during the payment process, and displaying order detail information before proceeding to the payment stage.

In addition, online purchase intention was found to be a significant antecedent of actual purchase. In this study, online purchase intention is explained by the following indicator: consumers' willingness to depend on online retailer for the security of their personal and confidential credit card data. Following this result, it is important for online retailers to assure consumers that they are able to secure the personal and confidential credit card data provided during online transaction. This guarantee can be communicated through a transaction security seal and privacy policy. Those features assure data security and in turn are expected to increase actual purchases. Another indicator of online purchase intention is the intention to shop online in the near future, which needs to be kept high by implementing the customer relationship management (CRM) approach and sending reminder emails or notifications to consumers about products they have seen during their visit to the online retailer's store. Email reminders are proven to increase conversion rates.

\section{Conclusions}

In general, this research provides insight into consumer behaviour in the online purchase context. Model development was based on criticisms towards TPB that the influence of intention on behaviour seems to oversimplify the decision-making process, and TPB does not give space or include factors that hinder behaviour in addition to factors that encourage behaviour. Moreover, field observation and empirical studies indicated that a transition from online purchase intention into actual purchase is not as simple. 
These become the rationale to examine the moderation effect of perceived transaction security and convenience on the relationship between online purchase intention and actual purchase.

The study findings can be summarised as follows. First, online purchase intention has a positive and significant impact on actual purchase. This aligns with TPB postulation and previous study findings. Second, perceived transaction security insignificantly moderates the influence of online purchase intention on actual purchase. This implies that an improvement in transaction security does not significantly strengthen the relationship between online purchase intention and actual purchase. Respondents' high familiarity in online shopping and the widely used COD method in Indonesia explains this insignificant moderation. Moreover, the lack of a credit card culture in emerging economies such as Indonesia makes online transaction security insignificant in encouraging actual purchase. Instead of using a credit card as a payment tool, consumers take advantage of the COD method or pay at an authorised convenience store. There are many authorised convenience stores where consumers can pay for their online purchases. Therefore, if online transaction security is low, the impact of online purchase intention on actual purchase remains strong since consumers can choose to pay through this offline channel.

Third, perceived transaction convenience significantly moderates the relationship between online purchase intention and actual purchase. This means the influence of online purchase intention on actual purchase strengthens significantly when transaction convenience increases. This reflects the reality in digitalisation era, where practicality, convenience, and transparency are increasingly sought by consumers when shopping. Online shopping is essentially a shopping activity that is carried out in an online platform with internet technology. Thus, the adoption of online shopping by consumers is closely related to technology adoption. When exploring factors that drive consumer intention to adopt online shopping, it is logical to link them with factors that drive technology adoption. In the technology acceptance model (TAM), it is stated that ease of use encourages technology adoption. The same thing can explain the conversion of online purchase intention into online purchase: if consumers perceive shopping on the online retailer's platform to be easy and convenient, the tendency of consumers will be higher to make an online purchase.

Retail industry players can utilise this study result to raise conversion rate by ensuring that they provide convenience in online transactions. This study has some limitations and there are abundant opportunities for further research. First, the research results cannot be generalised and applied equally well to other industries because the unique characteristics of an industry could alter a set of factors that influence purchase behaviour. Second, with this study's descriptive nature, there was no manipulation or control of the antecedents of online purchase behaviour as it would be in experimental design; thus, conclusions on the relationship between constructs in this study require further and continuous research. Future research can analyse the moderating effect of consumer demography characteristics and price fairness on the relationship between online purchase intention and actual purchase.

\section{Acknowledgements}

This research was supported by The Ministry of Research, Technology, and Higher Education of The Republic of Indonesia. We are also grateful for the insightful comments offered by the anonymous peer reviewers at The Ministry of Research, Technology, and Higher Education of The Republic of Indonesia on an earlier version of the manuscript.

We would also like to show our gratitude to I.B.A. Dharmanegara as Head of Management Study Program at Warmadewa University for sharing his pearls of wisdom with us during the course of this research, and for comments that greatly improved the manuscript.

\section{Funding}

This work was supported by The Ministry of Research, Technology, and Higher Education of The Republic of Indonesia under Grant number: 0971/L8/KM/2019.

\section{Author contributions}

Below are the authors' contributions to this study:

- Ni Luh Putu Indiani wrote the first draft of the article, validated the research methodology, prepared the questionnaires, and wrote the final article.

- Gabriel Aprinau Fahik collected data, conducted data analyses, and interpreted the result.

\section{Disclosure statement}

Authors do not have any competing financial, professional, or personal interests from other parties.

\section{References}

Akturan, U., \& Tezcan, N. (2012). Mobile banking adoption of the youth market: perceptions and intentions. Marketing Intelligence and Planning, 30(4), 444-459.

https://doi.org/10.1108/02634501211231928

Baymard Institute. (2019). Cart abandonment rate statistics. https://baymard.com/lists/cart-abandonment-rate

Bettman, J. R. (1973). Perceived risk and its components: A model and empirical test. Journal of Marketing Research, 10(2), 184-190. https://doi.org/10.2307/3149824

Bray, J. P. (2008). Consumer behaviour theory: approaches and models. http://eprints.bournemouth.ac.uk/ 10107/1/Consumer_Behaviour_Theory_-_Approaches_\%26_Models.pdf

Celik, H. (2011). Influence of social norms, perceived playfulness and online shopping anxiety on customers' adoption of online retail shopping. International Journal of Retail \& Distribution Management, 39(6), 390-413.

https://doi.org/10.1108/09590551111137967 
Chang, R. D., Fang, C. J., \& Tseng, Y. C. (2012) The effects of WebTrust assurance on consumers' web purchase decision. Online Information Review, 36(2), 218-240.

https://doi.org/10.1108/14684521211229048

Chen, Y. H., Hsu, I. C., \& Lin, C. C. (2010) Website attributes that increase consumer purchase intention: A conjoint analysis. Journal of Business Research, 63, 1007-1014. https://doi.org/10.1016/j.jbusres.2009.01.023

Childers, T. L., Carr, C. L., Peck, J., Carson, S. (2001). Hedonic and utilitarian motivations for online retail shopping behavior. Journal of Retailing, 77, 511-535. https://doi.org/10.1016/S0022-4359(01)00056-2

CNBC. (2019). Transaksi e-commerce RI 2018 capai Rp. 77 T, lompat 151\%. https://www.cnbcindonesia.com/tech/ 20190311101823-37-59800/wow-transaksi-e-commerce-ri2018-capai-rp-77-t-lompat-151

Cooper, D. R., \& Schindler, P. S. (2014). Business research methods. New York: McGraw-Hill.

Cramer, D., \& Howitt, D. (2004) The SAGE dictionary of statistics ( $1^{\text {st }}$ Ed.). London: SAGE Publication Ltd. https://doi.org/10.4135/9780857020123

Cunningham, S. M. (1967). The major dimension of perceived risk. Risk taking and information handling in consumer behavior (pp. 82-108). Harvard University Press.

Cunningham, L. F., Gerlach, J. H., Harper, M. D., \& Young, C. E. (2005). Perceived risk and the consumer buying process: internet airline reservations. International Journal of Service Industry Management, 16(4), 357-372.

https://doi.org/10.1108/09564230510614004

D’Alessandro, S., Girardi, A., \& Tiangsoongnern, L. (2012). Perceived risk and trust as antecedents of online purchasing behavior in the USA gemstones industry. Asia Pacific Journal of Marketing and Logistics, 24(3), 433-460.

https://doi.org/10.1108/13555851211237902

Ellen, S. (2018). Slovin's formula sampling techniques. https://sciencing.com/pps-sampling-6663947.html

Festinger, L. (1957). A theory of cognitive dissonance. Stanford CA: Stanford University Press.

Fogel, J., \& Schneider, M. (2010). Understanding designer clothing purchases over the internet. Journal of Fashion Marketing and Management, 14(3), 367-396.

https://doi.org/10.1108/13612021011061843

Ganac, C. G. (2018). Investigating consumer optimum stimulation level and exploratory online buying behavior. $D L S U$ Business \& Economics Review, 28(1), 67-85. https://doi.org/10.1016/S0167-8116(02)00063-0

Gao, L., \& Bai, X. (2014). A unified perspective on the factors influencing consumer acceptance of internet of things technology. Asia Pacific Journal of Marketing and Logistics, 26(2), 211-231. https://doi.org/10.1108/APJML-06-2013-0061

Ghozali, I., \& Latan, H. (2012). Partial Least Square: Konsep, Teknik, dan Aplikasi SmartPLS 2.0. Semarang: Badan Penerbit Universitas Diponegoro.

Guo, Y., \& Barnes, S. (2011). Purchase behavior in virtual worlds: an empirical investigation in second life. Information and Management, 48, 303-312.

https://doi.org/10.1016/j.im.2011.07.004

Hair, Jr J. F., Black, W. C., Babin, B. J., \& Anderson, R. E. (2010). Multivariate data analysis a global perspective (7th ed.). New Jersey: Pearson Education.

Hijrah, L. (2017). Segmentasi konsumen pada pasar online di Indonesia. Forum Ekonomi, 19(2), 210-219.

http://journal.feb.unmul.ac.id/index.php/FORUMEKONOMI
Hsieh, J. Y., \& Liao, P. W. (2011). Antecedents and moderators of online shopping behavior in undergraduate students. Social Behavior and Personality, 39(9), 1271-1280. https://doi.org/10.2224/sbp.2011.39.9.1271

Indiani, N. L. P., Rahyuda, I. K., Yasa, N. N. K., Sukaatmadja IPG (2015). Perceived risk and trust as major determinants of actual purchase, transcending the influence of intention. ASEAN Marketing Journal, 7(1), 1-13. https://doi.org/10.21002/amj.v7i1.4601

Kim, M. J., Chung, N., \& Lee, C. K. (2011). The effect of perceived trust on electronic commerce: shopping online for tourism products and services in South Korea. Tourism Management, 32, 256-265. https://doi.org/10.1016/j.tourman.2010.01.011

Kim, J. H., \& Lennon, S. J. (2010). Information available on a website: effects on consumer's shopping outcomes. Journal of Fashion Marketing and Management, 14(2), 247-262. https://doi.org/10.1108/13612021011046093

Kim, J., Lennon, S. J. (2013). Effects of reputation and website quality on online consumers' emotion, perceived risk and purchase intention. Journal of Research in Interactive Marketing, 7(1), 33-56. https://doi.org/10.1108/17505931311316734

Kompas. (2018). 80 Persen Konsumen Belanja Online Orang Muda dan Wanita.

https://lifestyle.kompas.com/read/2018/03/22/155001820/80persen-konsumen-belanja-online-orang-muda-dan-wanita?p age $=$ all

Kompas. (2018). Jumlah Pembeli Online Indonesia Capai 11,9 Persen dari Populasi.

https://ekonomi.kompas.com/read/2018/09/07/164100326/ jumlah-pembeli-online-indonesia-capai-119-persen-daripopulasi.

Kowalska, M. (2012). The internet impact on market behavior of young consumers. Journal of International Studies, 5(1), 101-106. https://www.jois.eu/files/KowalskaV5_N1.pdf

Lee, H. H. H., Au, N., \& Law, R. (2013). Presentation formats of policy statements on hotel websites and privacy concerns: a multimedia learning theory perspective. Journal of Hospitality and Tourism Research, 37(4), 470-489.

https://doi.org/10.1177/1096348012436384

Lendel, V., \& Varmus, M. (2015). Proposal of innovative approaches of relationship marketing in business. Business: Theory and Practice, 16(1), 63-74.

https://doi.org/10.3846/btp.2015.434

Lim, W. M. (2013) Toward a theory of online buyer behavior using structural equation modeling. Modern Applied Science, 7(10), 34-42. https://doi.org/10.5539/mas.v7n10p34

Lin, W. B. (2008). Construction of on-line consumer behavior models: a comparative study of industries in Taiwan. International Journal of Commerce and Management, 18(2), 123-149. https://doi.org/10.1108/10569210810895221

Ling, K. C., Daud, D. B., Piew, T. H., Keoy, K. H., \& Hassan, P. (2011). Perceived risk, perceived technology, online trust for the online purchase intention in Malaysia. International Journal of Business and Management, 6(6), 167-182. https://doi.org/10.5539/ijbm.v6n6p167

Liu, C., \& Forsythe, S. (2010). Post-adoption online shopping continuance. International Journal of Retail and Distribution Management, 38(2), 97-114. https://doi.org/10.1108/09590551011020110

Liu, M. T., Brock, J. L., Shi, G. C., Chu, R., \& Tseng, T. H. (2013). Perceived benefits, perceived risk, and trust. Asia Pacific Journal of Marketing and Logistics, 25(2), 225-248.

https://doi.org/10.1108/13555851311314031 
Lowry, P. B., Moody, G., Vance, A., Jensen, M., Jenkins, J., \& Wells, T. (2012). Using an elaboration likelihood approach to better understand the persuasiveness of website privacy assurance cues for online consumers. Journal of The American Society for Information Science and Technology, 63(4), 755776. https://doi.org/10.1002/asi.21705

Marketeers. (2018). Lima kota Indonesia dengan jumlah pembelanja online terbesar. http://marketeers.com/lima-kota-indonesia-dengan-jumlah-pembelanja-online-terbesar/

Mei, J. Y., Nan, Z. Y., Ping, Z. W. (2011, 6-8 May). Decision model research of customer first online shopping based on reference group influence. In 2011 International Conference on E-Business and E-Government (ICEE). Shanghai. https://doi.org/10.1109/ICEBEG.2011.5881762

Monsuwe, T., Dellaert, B. G. C., \& de Ruyter, J. C. (2004). What drives consumers to shop online? A literature review. International Journal of Service Industry Management, 15(1), 102121. https://doi.org/10.1108/09564230410523358

Mullikin, J. L. (2003). Beyond reference price: understanding consumer's encounter with unexpected prices. Journal of Product \& Brand Management, 12(3), 140-153. https://doi.org/10.1108/10610420310476906

Negra, A., \& Mzoughi, M. N. (2012). How wise are online procrastinators? A scale development. Internet Research, 22(4), 426-442. https://doi.org/10.1108/10662241211250971

Nepomuceno, M. V., Laroche, M., Richard, M. O., \& Eggerd, A. (2012). Relationship between intangibility and perceived risk: moderating effect of privacy, system security and general security concern. Journal of Consumer Marketing, 29(3), 176189. https://doi.org/10.1108/07363761211221701

Ozkan, S., Bindusara, G., \& Hackney, R. (2010). Facilitating the adoption of e-payment systems: theoritical constructs and empirical analysis. Journal of Enterprise Information Management, 23(3), 305-325. https://doi.org/10.1108/17410391011036085

Park, C., \& Jun, J. K. (2003). A cross-cultural comparison of internet buying behavior. International Marketing Review, 20(5), 534-553. https://doi.org/10.1108/02651330310498771

Park, C. H., \& Kim, Y. G. (2006). The effect of information satisfaction and relational benefit on consumers online site commitments. Journal of Electronic Commerce in Organizations, 4(1), 70-90. https://doi.org/10.4018/jeco.2006010105

Putri, A. (2016, November). Survei E-commerce Indonesia. SWA, 24, 42-45. https://doi.org/10.25124/liski.v3i1.805

Rajamma, R. K., Paswan, A. K., \& Hossain, M. M. (2009). Why do shoppers abandon shopping cart? Perceived waiting time, risk, and transaction inconvenience. Journal of Product and Brand Management, 18(3), 188-197. https://doi.org/10.1108/10610420910957816

Raman, A., \& Annamalai, V. (2011). Web services and e-shopping decisions: a study on Malaysian e-Consumer. IJCA
Special Issue on: Wireless Information Networks \& Business Information System, 2, 54-60. https://www.researchgate.net/ publication/286456862_Web_Services_and_e-Shopping_ Decisions_A_Study_on_Malaysian_e-Consumer

Roy, S., Raju, A., \& Mandal, S. (2017). An empirical investigation of e-retailer agility, customer satisfaction, commitment, and loyalty. Business: Theory and Practice, 18, 97-108. https://doi.org/10.3846/btp.2017.011

Sahney, S., Ghosh, K., \& Shrivastava, A. (2013). Conceptualizing consumer trust in online buying behavior: an empirical inquiry and model development in Indian context. Journal of Asia Business Studies, 7(3), 278-298. https://doi.org/10.1108/JABS-Jul-2011-0038

Sarwono, J. (2013). 12 Jurus Ampuh SPSS untuk Riset Skripsi (1st ed.). Jakarta: Elex Media Computindo.

Shen, Y., Li, S., DeMoss, M. (2012). The effect of quantitative electronic word of mouth on consumer perceived product quality. International Journal of Management and Marketing Research, 5(2), 19-29. http://www.theibfr2.com/RePEc/ibf/ ijmmre/ijmmr-v5n2-2012/IJMMR-V5N2-2012-2.pdf

Sheppard, B. H. (1988). The theory of reasoned action: a metaanalysis of past research with recommendations for modifications and future research. The Journal of Consumer Research, 15(3), 325-343. https://doi.org/10.1086/209170

Sims, J., \& Xu, L. (2012, 27 March). Perceived risk of online shopping: differences between the UK and China. In UK Academy for Information Systems Conference Proceedings. UK. http://aisel.aisnet.org/ukais2012/25

Thongpapanl, N., \& Ashraf, A. R. (2011). Enhancing online performance through website content and personalization. Journal of Computer Information Systems, 52(1), 3-13. https://doi.org/10.1080/08874417.2011.11645517

Wartaekonomi. (2019). Pertumbuhan E-Commerce Pesat di Indonesia. https://www.wartaekonomi.co.id/read216302/pertumbuhan-e-commerce-pesat-di-indonesia.html

Wilson, R. D. (2010). Using clickstream data to enhance business to business website performance. Journal of Business and Industrial Marketing, 25(3), 177-187.

https://doi.org/10.1108/08858621011027768

Xu, B., Lin, Z., \& Shao, B. (2010). Factors affecting consumer behaviors in online buy-it-now auctions. Internet Research, 20(5), 509-526. https://doi.org/10.1108/10662241011084086

Zhao, A. L., Lloyd, S. H., Ward, P., Gooude, M. M. H. (2008). Perceived risk and Chinese consumers' internet banking services adoption. International Journal of Bank Marketing, 26(7), 505-525. https://doi.org/10.1108/02652320810913864

Zhao, A. L., Lewis, N. K., Lloyd, S. H., \& Ward, P. (2010). Adoption of internet banking services in China: is it all about trust? International Journal of Bank Marketing, 28(1), 7-26. https://doi.org/10.1108/02652321011013562 